Бабій Микола
кандидат психологічних наук, доцент кафедри
педагогічної та вікової психології
Волинського національного університету
імені Лесі Українки
https: //orcid.org/0000-0002-9550-3166

DOI https://doi.org/10.35619/praprv.v1i16.208

\title{
ВІКОВА РЕДУКЦІЯ ПРОФЕСІЙНОГО ЗДОРОВ'Я ВЧИТЕЛІВ У СУЧАСНІЙ ШКОЛІ
}

\begin{abstract}
Анотація. У статті розкривається проблема вікової редукції професійного здоров'я y вчителів. Вона пов'язана з детермінантами, які викликають феномен емоційнопрофесійного вигорання у педагогів різного освітнього профілю, різного віку та з різним стажем роботи. Визначена проблема вивчалася у площині емоційного виснаження, шчо породжує невідповідності між особистісними можливостями, ресурсами та професійними обов'язками. Цей синдром редукиії (знесилення) бере свій початок із негараздів персональної взаємодї з учнями ци включає генезис негативного ставлення до всього, щэо прямо чи опосередковано стосується педагогічної діяльності.
\end{abstract}

Для підтвердження аргументів, автор представив результати власного діагностичного дослідження причин редукиї професійного здоров'я у педагогів різного віку та стажем роботи. Вони вказують на те, що тривале, постійне перебуванням під пресом негативних ситуаиій породжує відповідні почуття, які негативно позначається на фізичному та психічному здоров'ю вчителя. Збереження иієї тендениії спонукає до зростання рівнів емоиійного знесилення, деперсоналізації, падіння рівня особистого задоволення та редукиії власних досягнень, які $\epsilon$ показниками емоційно-професійного вигорання.

Ключові слова: навчання, редукція, педагогічна діяльність, професійно-емоиійне вигорання, хронічна втома, комунікабельність, емоційне виснаження, стрес, генезис.

Постановка проблеми. Негаразди 3 професійним здоров'ям вчителя викликаються багатьма факторами, на які він не здатен вплинути, або уникнути. До одного з таких відноситься синдром емоційно-професійного вигорання як результат невідповідності між особистістю та професійними обов'язками. Він бере свій початок зі стресу міжособистісної взаємодії й включає розвиток негативного відношення до всього, що прямо чи опосередковано стосується педагогічної діяльності (Максименко, 2006).

Часто у науковій літературі поняття «емоційне» та «професійне» вигорання або розділяють, або ототожнюють. Фактично - це синоніми, оскільки перший термін «емоційне» стосується безпосередньо фону фахової діяльності. У даному випадку людські почуття виступають індикатором, який засвідчує: чи задоволена людина роботою чи ні. Загалом термін «емоційне вигорання», вважається більш ширшим, оскільки стосується негараздів не тільки пов'язаних з педагогічною діяльністю, а також і тих, що діють за межами професійних обов'язків (Водоп'янова 2008).

Аналіз останніх досліджень і публікацій. Синдром вигорання входить до 11-го видання Міжнародної класифікації хвороб (МКХ) як явище, що виникло внаслідок хронічного стресу на роботі (Михайлов, 2001). Згідно з МКХ-11, вигорання - синдром, що виникає внаслідок хронічного стресу на робочому місці. Тобто хронічний емоційна напруга на роботі може призвести до вигорання. Сам термін «професійне вигорання» ввів американський психіатр Фрейденбергер у 1974 році для характеристики психічного стану здорових людей, які працюють у системі «людина-людина»: лікарі, юристи, соціальні працівники, психіатри, психологи, педагоги (Михайлов, 2001).

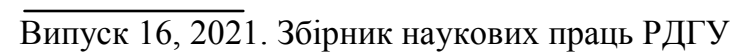


Проблема синдрому професійного вигорання вивчалася та знайшла своє відображення у роботах зарубіжних й вітчизняних науковців, присвячених змісту та структурі цього явища. Генезис, зазначеного вище емоційного порушення, має ступінчатий характер, його ознаки проявляються не відразу. Найчастіше, навіть сам суб'єкт не спроможний вчасно виявити та розпізнати симптоматику.

До основних ознак емоційно-професійного вигорання відносять:

- стан постійного недосипання, особливо помітний вранці, коли, тільки прокинувшись, ви не відчуваєте, що виспались та відпочили;

- зниження працездатності полягає у труднощах розв'язку завдання, які раніше виконували легко й швидко, а згодом вимагають більше часу й додаткових зусиль для пошуку рішень, вам стає складніше переключатися між різними завданнями, а незаплановані завдання викликають сильний стрес та агресію;

- часті фізичні негаразди зі здоров'ям: постійні головні болі, застуда, ломота в тілі, хронічні захворювання,

- втрата ентузіазму в роботі породжує зникнення інтересу до завдань й фахових питань, які раніше сприймались з азартом, а розв'язок захоплював й додавав снаги на нові звитяги;

- зростання кількості та якості помилок: від непомітних похибок до серйозних недоліків у результаті регресу уважності, відсутністю ресурсів для концентрації уваги, а згодом сповільнюються розумові здібності.

- острах перед нововведеннями, які на початку кар'єри викликали інтерес й цікавість, то тепер, інноваційні варіанти лякають, мало того, тепер втілення інноваційних підходів й методів на практиці розглядається через призму критики і небажанні впроваджувати щось нове й прогресивне бо необхідна життєва енергія просто відсутня, а діють захисні механізми у вигляді внутрішнього опору;

- підвищена дратівливість переростає в часті спалахи гніву та агресію у взаєминах 3 колегами, у відношенні до робочих процесів, своїх завдань, педагогічного колективу й школи у цілому;

- зменшення кола соціальних контактів та уникнення нових, навіть дуже корисних знайомств;

- песимістичні настрої у діяльності, небажання щодо власного професійного розвитку, глибока байдужість до роботи у школі й до своїх обов'язків;

- втрата сенсу у якості виконання професійних обов'язків, повне розчарування у самій професії, інколи, породжує прагнення повністю змінити напрям професійної діяльності, навіть якщо присвятили йому більшу частину життя (Шитова 1997).

Детермінанти емоційно-професійного вигорання:

- нетворчий характер роботи, одноманітність за схемою «дім-робота-дім»;

- малі можливості просування по службовій драбині;

- відсутність незалежності в роботі;

- неможливість усамітнення;

- ізоляція від колег, немає часу, щоб з ними неформально поспілкуватися на особисті теми;

- вимушений характер професійного спілкування;

- відсутність можливості або невміння скидати накопичені негативні переживання;

- $\quad$ невирішені особисті проблеми (Дудяк, 2007).

Вважається, що до емоційно - професійного вигорання найбільше схильна вікова категорія 28-42 роки, коли у людини відбувається переоцінка цінностей та пріоритетів. Наскільки вірні ці твердження, показало наше власне дослідження.

Мета статті. Наукове дослідженні було націлене на дослідження вікової редукції професійного здоров’я педагогів у сучасній школі.

Виклад основного матеріалу досліджень. Дослідження проводилося у 2020 році. У ньому брали участь педагоги ЗОШ № 1; №3; №4 комунального закладу «Луцький навчально- 
реабілітаційний центр» та НВК гімназії № 14 м. Луцьк. Загальний обсяг вибірки - 75 осіб. За віком вибірка була диференційована на три групи : група А - віковий діапазон 30- 40 років; група В - діапазон 40 - 50 років та група $\mathrm{C}$ - вік учасників 50 - 60 років. Вчителі пенсійного віку у досліджені участі не приймали.

Для діагностики були використані три методики. Перша, методика «Дослідження синдрому «вигорання» Грінберга. Вона дозволяє визначити рівні вигорання за відповідними балами: низький 0-7 середній 8-14 високий 15- 20. Наступна «Діагностика професійного «вигорання» за авторства Маслач та Джексон (адаптація Водопьяновой). Вона - дозволяла теж, визначити рівні «професійного вигорання» за наступними показниками емоційне виснаження, деперсоналізація, редукція особистих досягнень. Це компоненти моделі синдрому «вигорання» запропонованою дослідниками Маслач та Джексон.

Емоиійне виснаження розглядається як основна складова «професійного вигорання» та характеризується заниженим емоційним фоном, байдужістю або емоційним перенасиченням. Деперсоналізація проявляється у деформації стосунків з іншими людьми. В одних випадках це може бути зростання залежності від інших людей, у інших зростання негативізму, цинічності налаштувань і почуттів щодо інших людей (учнів, колег, підлеглих тощо).

Редукиія особистих досягнень полягає або в тенденції до негативного оцінювання себе, своїх професійних досягнень та успіхів, негативізмі щодо службової гідності й можливостей, або у нівелюванні особистої гідності, обмеженні своїх можливостей, обов'язків щодо інших тощо. Методика «Оцінка власного потенціалу «вигорання» дає можливість дослідити такі основні компоненти «вигорання»: деперсоналізація, особиста задоволеність, емоційне виснаження. Першому й третьому компоненту ми вже дали визначення вище. Особиста задоволеність - «зануреність» у роботу та персональна задоволеність від цього.

Проаналізуємо результати за методикою «Дослідження синдрому «вигорання» Гринберга та порівняємо їх. Першою була група А. Стаж роботи у школі від 7 до 17 років. Результати показали, що у більшості переважає низький рівень синдрому вигорання (64\%), середній у $32 \%$ осіб й високий у однієї особи (4\% відповідно). Розглянемо результати групи В. До їі складу входять вчителі віком від 40 до 50 років. За показниками помітне зростання рівня синдрому вигорання. Особливо це стосується вчителів, вік яких наближається до 50 річної позначки. У більшості з них (56\%) рівень синдрому середній (див. рис. 1).

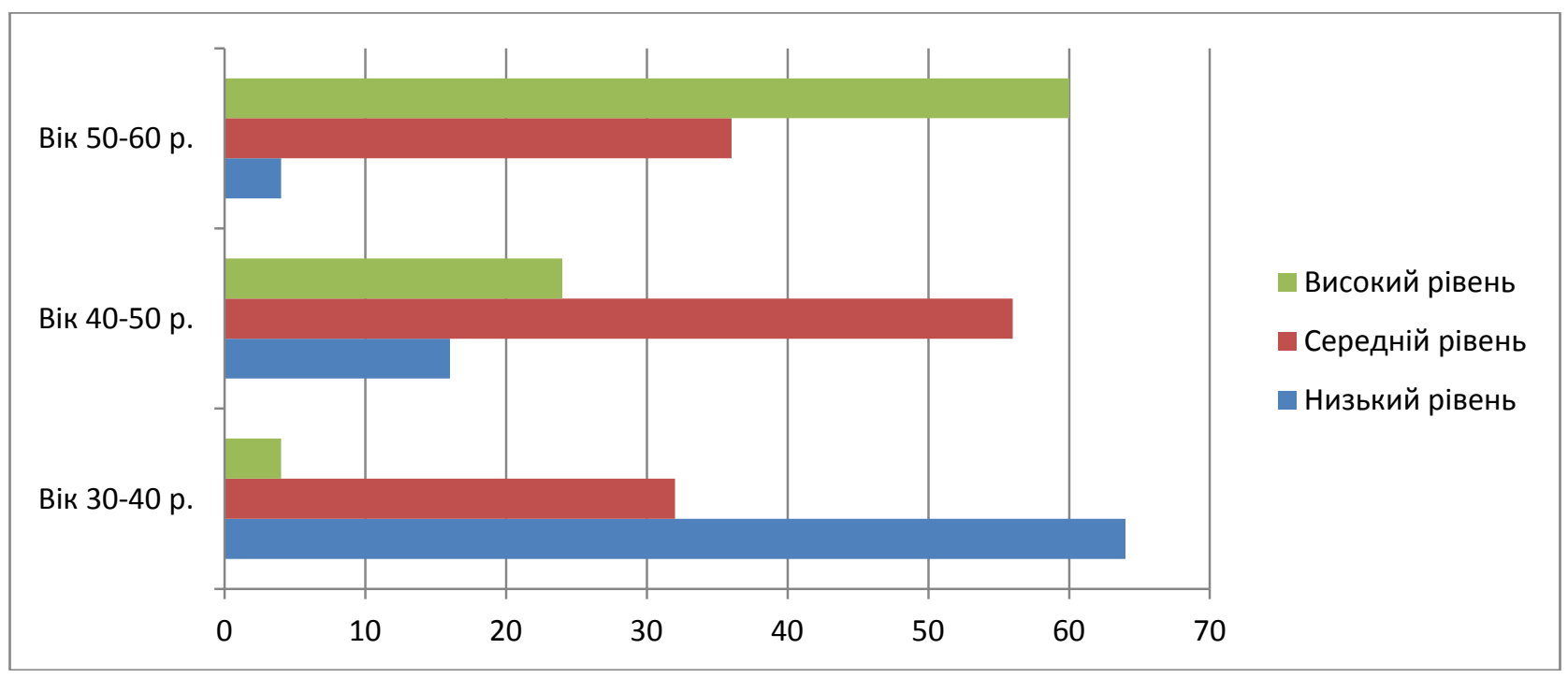

Рис. 1. Результати за методикою Дж. Грінберга 
Високий рівень втоми зафіксовано у 24 \% респондентів, низький - у 16\%. Варто зазначити, що у педагогів, які працюють у реабілітаційному центрі рівень синдрому вищий, у порівнянні з вчителями загальноосвітніх школах. До прикладу із 6 осіб групи В у чотирьох виявили високий рівень.

Розглянемо результати групи С. За результатами дослідження ми встановили, що у $60 \%$ вчителів, із цієї групи, спостерігається високий рівень синдрому, 36\% - середній та $4 \%$ низький.

Наступною була методика «Діагностика професійного «вигорання». Воно визначається за наступними показниками:

- емочійне виснаження основна складова «професійного вигорання», яка характеризується заниженим емоційним фоном, байдужістю або емоційним перенасиченням;

- деперсоналізачія деформації стосунків з іншими людьми. В одних випадках це може бути зростання залежності від інших людей, у інших - зростання негативізму, цинічного налаштування до почуттів інших людей (учнів, колег, підлеглих тощо);

- редукція особистих досягнень - полягає або в тенденції до негативного оцінювання себе, своїх професійних досягнень та успіхів, негативізмі щодо службової гідності й можливостей, або у нівелюванні особистої гідності, обмеженні своїх можливостей, обов'язків щодо інших тощо.

Результати, отримані у групі А подані на рисунку. У процентному співвідношенні було отримано наступне: високий рівень емоційного виснаження виявлено у $16 \%$ респондентів, середній - 52\%, низький - 32\%; деперсоналізація - високий $0 \%$, середній $24 \%$, низький - 76\%; редукція особистих досягнень: у 20\% високий, середній $-64 \%$, низький $-16 \%$

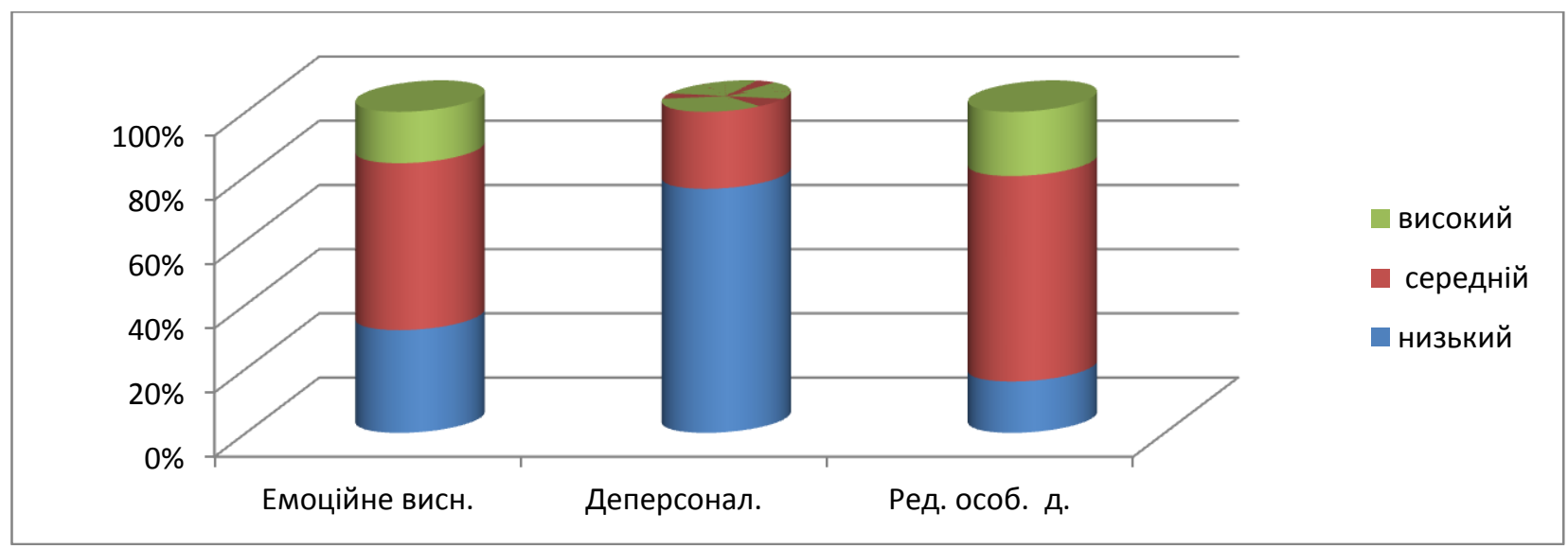

Рис. 2. Результати групи А за методикою "Діагностика професійного «вигорання»

Проаналізуємо за цими ж показниками результати групи В. До ії складу входять педагоги віком від 40 до 50 років. Високий рівень емоційного виснаження виявлено у 40\% респондентів, середній - 56\%, низький - 4\%; деперсоналізація - високий $36 \%$, середній $64 \%$, низький - 0\%; редукція особистих досягнень: у $50 \%$ високий, середній $-50 \%$, низький $-0 \%$.

У третій підгрупі респондентів (групі С) ми виявили наступні результати: емоційне виснаження у $36 \%$ високий, $64 \%$ - середній рівень; високий рівень деперсоналізації у $32 \%$ респондентів, середній - 48\%, низький - $20 \%$; високий рівень редукції особистих досягнень $88 \%$, середній $-12 \%$. Підсумовуючи їх, ми помітили тенденцію до росту рівня показників професійного вигорання у порівнянні з групою А та В (див. рис. 3). 


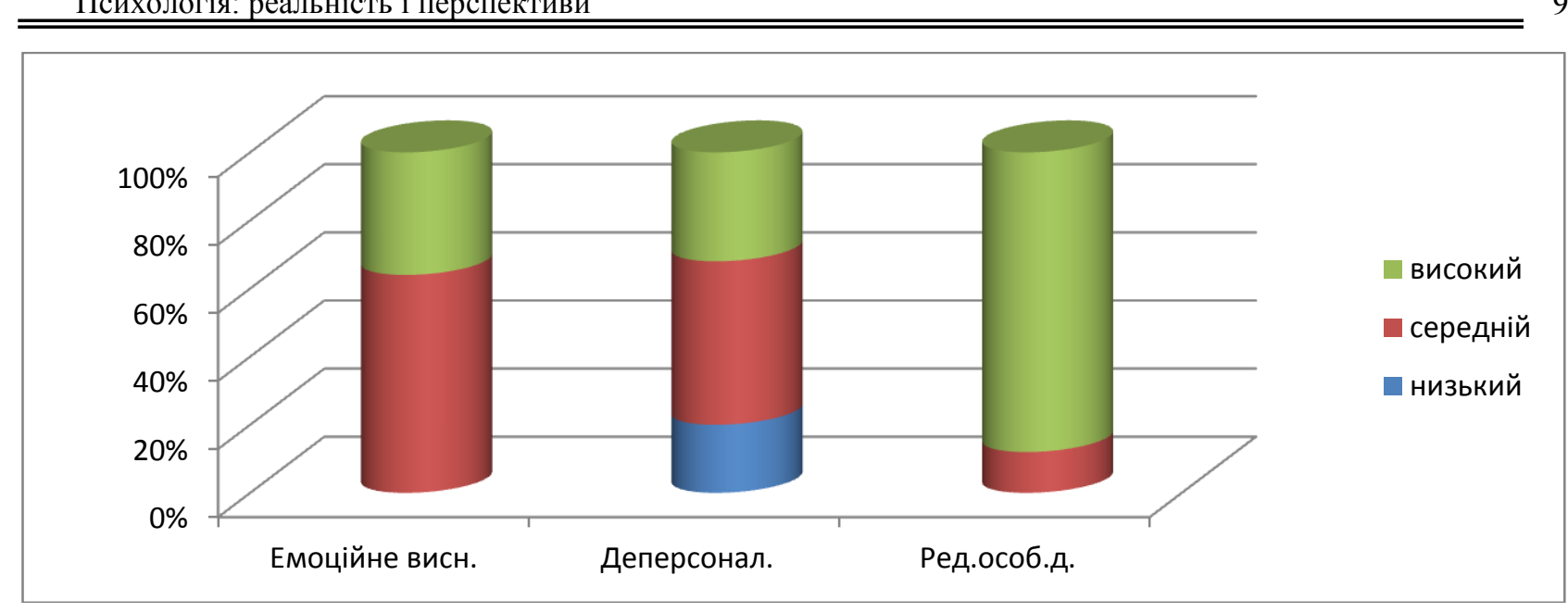

\section{Рис. 3. Результати групи С за методикою «Діагностика професійного вигорання".}

Третьою методикою була «Оцінка власного потенціалу «вигорання». Розпочнемо 3 групи А. Емоційне виснаження: високий рівень у $12 \%$ респондентів, середній - 56\%, низький $-32 \%$. Деперсоналізація: середній - 32\%, низький - 68\%. Особиста задоволеність: середній рівень - 68\%, низький рівень у $32 \%$ відповідно (див. рис. 4).

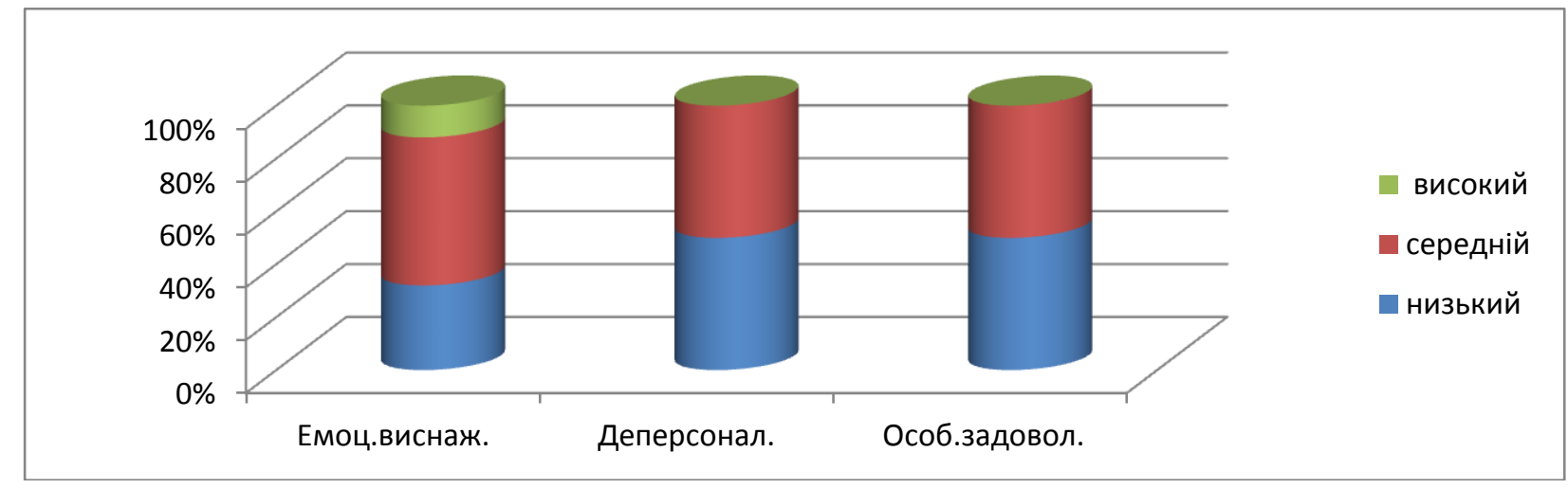

\section{Рис. 4. Результати групи А за методикою «Оцінка власного потенціалу «вигорання"}

У групі В ці показники розподілились наступним чином: емоційне виснаження: високий рівень у $48 \%$ респондентів, середній - 52\%; деперсоналізація: високий - 48\%, середній - 52\%; особиста задоволеність: середній рівень - 56\%, низький рівень у $44 \%$ відповідно.

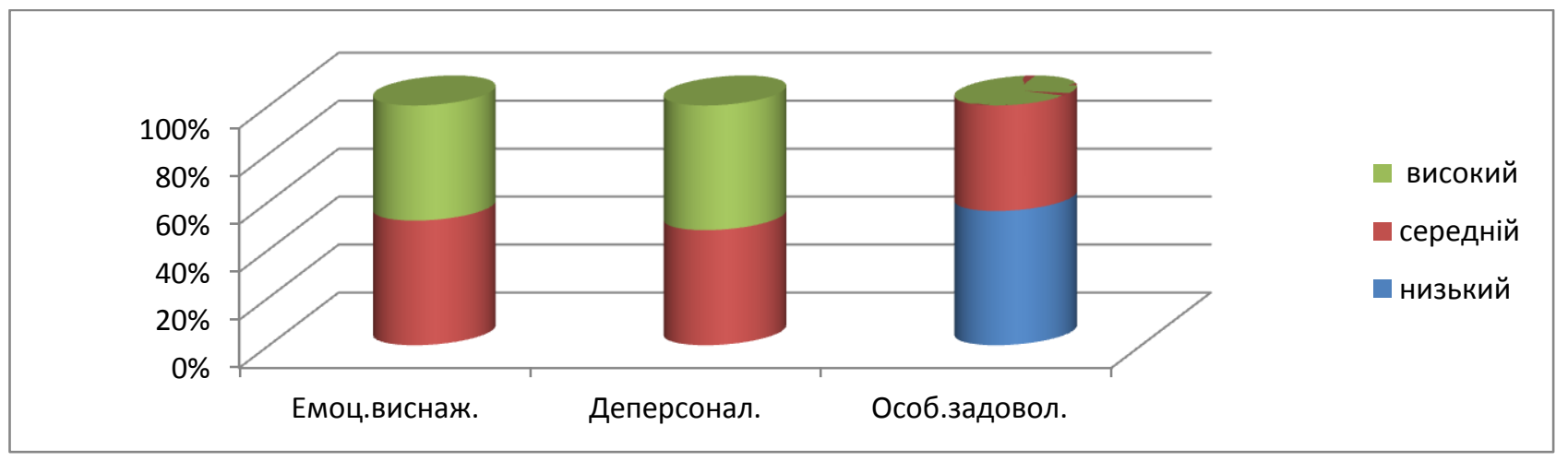

Рис. 6. Результати групи В за методикою «Оцінка власного потенціалу «вигорання" 
Розглянемо результати найстарших учасників дослідження (пігрупа С). Високий рівень емоційного виснаження діагностовано у 72\% респондентів, середній - у 28\%. Деперсоналізація: високий - $32 \%$, середній - 56\%, низький - 12\%. Особиста задоволеність: середній рівень - 16\%, низький рівень у $84 \%$, відповідно.

Висновки та перспективи дослідження. Аналізуючи результати ми помітили редукцію психічного здоров'я у сучасній школі. Педагогічна праця передбачає комунікацію 3 учнями, під час якої передаються знання, уміння та навички. Вчитель виступає як у ролі передавача інформації так й приймача, окрім того до його обов'язків входить контроль й корекція навчального процесу. Відповідно, його психіка перебуває під постійним тиском відповідальності, що не може не позначитись на його психіці. Тривале, постійне перебування під таким пресом відповідальності негативно позначається на психічному здоров'ю і як наслідок з віком зростають рівні емоційного виснаження, деперсоналізації, редукції власних досягнень, падає рівень особистого задоволення. Все це $є$ показниками емоційного професійного вигорання, про що красномовно засвідчують результати нашого дослідження.

Починаючи з 35-36 років й надалі, помітне погіршення ситуації. Парадоксальність ситуації у тому, що навіть при невеликому стажі професійної діяльності, умови педагогічної праці уже спричиняють появу ознак руйнації психічного здоров'я. Не зважаючи на те, що 3 кожним роком вчитель набуває досвіду співпраці з учнями й мав би, на нашу думку, набути навичок вмілого реагувати на негативні виклики та не доводити комунікативну взаємодію до високого рівня емоційної напруженості.

Перспективу подальших досліджень ми вбачаємо у вивченні рівнів впливу педагогічної діяльності на емоційний стан вчителів з різним типом нервової системи.

\section{СПИСОК ПОСИЛАНЬ}

Азарова, Т. В. (2007). Вчимося вирішувати проблеми. Київ: Главник.

Водопьянова, Н. Е. (2008). Синдром выгорания: диагностика и профилактика. СанктПетербург: Питер.

Дудяк, В. (2007). Емоційне вигорання. Київ: Главник.

Максименко, С. Д. (2006). Синдром «професійного вигорання» та професійна кар'єра працівників освітніх організацій: гендерні аспекти. Київ: Міленіум.

Михайлов, Б. В. (2001). Синдром «выгорания», его причины и способы коррекции. Apхивы психиатрии, 4, 32-36.

Шитова, И. Ю. (1997). Проблемы педагогической профессии и пути их разрешения. Ученые записки СГУ, 3, 20-25.

\section{REFERENCES}

Azarova, T. V. (2007). Vchymosia vyrishuvaty problemy [Learning to solve problems]. Kyiv: Hlavnyk. [in Ukrainian].

Dudiak, V. (2007). Emotsiine vyhorannia [Emotional burnout]. Kyiv: Hlavnyk. [in Ukrainian].

Maksymenko, S. D. (2006). Syndrom "profesiinoho vyhorannia» ta profesiina kariera pratsivnykiv osvitnikh orhanizatsii: henderni aspekty [The syndrome of "professional burnout" and the professional career of employees of educational organizations: gender aspects]. Kyiv: Milenium. [in Ukrainian].

Mykhailov, B. V. (2001). Syndrom «vyhoranyia», eho prychynы y sposobi korrektsyy [Burnout syndrome, its causes and methods of correction]. Arkhyvi psykhyatryy, 4, 32-36. [in Russian].

Shytova, Y. Yu. (1997). Problemu pedahohycheskoi professyy y puty ih razreshenyia [Problems of the teaching profession and ways to solve them]. Uchenble zapysky SHU, 3, 20-25. [in Russian].

Vodopianova, N. E. (2008). Syndrom vyhoranyia: dyahnostyka y profylaktyka [Burnout syndrome: diagnosis and prevention]. Sankt-Peterburh: Pyter. [in Russian]. 


\title{
PROFESSIONAL HEALTH REDUCTION AMONG TEACHERS AT MODERN SCHOOL
}

\author{
Mykola Babii \\ Candidate of Psychological Sciences, Associate Professor \\ Department of Pedagogical and Age Psychology \\ Eastern European National Lesya Ukrainka University \\ https://orcid.org/0000-0002-9550-3166
}

DOI https://doi.org/10.35619/praprv.v1i16.208

The article reveals the problem of age reduction of professional health in teachers. It is associated with determinants who cause the phenomenon of emotionally professional burnout in teachers of a different educational profile, of different ages and with different work experience. A certain problem was studied in the plane of emotional exhaustion, which generates inconsistencies between personal capabilities, resources and professional duties.

This reduction syndrome (decay of forces) originates with the problems of personal interaction with students and includes the genesis of a negative attitude to everything that directly or indirectly concerns pedagogical activities. To confirm the arguments, the author organized and conducted his own study of an announced problem. It was conducted in 2020, teachers of educational institutions of the city of Lutsk took part in it. A total of 75 people and aged 30 to 60 years old.

For diagnosis, we used three techniques, they allowed to determine the levels of burnout in the following indicators: emotional depletion, depersonalization, reduction of personal achievements, personal satisfaction. According to the results, we found that a long, permanent stay under the press of negative situations generates response senses, which negatively affects the physical and mental health of the teacher.

So, starting from the age of 35-36 years and later, their progress is noticeable in our respondents. The paradoxicality of the situation is that with a small work, the conditions of pedagogical labor are already encouraged to destroy mental health. Despite the fact that every year the teacher acquires the experience of cooperation with students and should, in our opinion, to acquire skills to skillfully respond to negative challenges and cannot communicate communicative interaction towards a high level of emotional tension. The preservation of this trend encourages the growth of the levels of emotional decline, depersonalization, the fall in the level of personal pleasure and reduction of their own achievements, which are indicators of the reduction of professional health.

Key words: training, reduction, pedagogical activities, professional-emotional burnout, chronic fatigue, sociability, emotional exhaustion, stress, genesis. 